\title{
Relations between Grandparents and Grandchildren in the Context of the Family System
}

\author{
Oliver Arránz Becker, Anja Steinbach
}

\begin{abstract}
The demographic change which has taken place in recent decades, and in particular the considerable increase in life expectancy, has resulted in intergenerational relationships that are lasting much longer. Despite the increase in people's median age at first child birth, members of different generations now have the opportunity to live together for periods that are unparalleled in human history. Especially the medical and technical progress has led to grandparents being increasingly capable in both health and cognitive terms at an advanced age that they provide active support for their children and grandchildren in many ways. This article addresses the question to what extent the relationship potentials - also against the background of modernisation processes within society (e.g. increasing demands as to mobility, problems in reconciling family and work) - are transformed into actual support by grandparents for the grandchildren's generation. The analyses are based on data from the parents of the primary respondents ("anchor persons") in the German Family Panel (Beziehungs- und Familienpanel - pairfam, 2nd wave 2009/2010, parents' questionnaire) with a grandchild aged between 8 and 15 . The significance of various factors influencing the strength of relationships between grandparents and their grandchildren is empirically examined. Firstly, social-structural characteristics and family-related attitudes on the part of the members of the various generations are considered, and secondly, various family members' personal and social resources. All in all, it is revealed that grandparent-grandchild relationships are largely independent from personal resources such as employment status, but that they are associated with social resources, that is the relationships between grandparents and parents, as well as with grandparents' partnership status. Moreover, there are pronounced regional differences (i.e., stronger grandparent-grandchild relations in Eastern Germany) and a positive impact of familialism.
\end{abstract}

Keywords: Relationships between generations · Grandparents · Grandchildren · Intergenerational support $\cdot$ pairfam 


\section{Introduction}

Grandparent-grandchild relationships form a major part of the solidarity and relationship structure within families; this was already documented by initial research work roughly fifty years ago (Neugarten/Weinstein 1964). Most studies have found that grandparents see their role positively. Furthermore, a positive identity as a grandparent, as well as close ties between grandparents and grandchildren, promote well-being (Kaufman/EIder 2003) and mental health (e.g. a greater self esteem and a less pronounced tendency towards depression) among grandparents (Kivnick 1982; Reitzes/Mutran 2004) and grandchildren (Ruiz/Silverstein 2007). The fact that, nonetheless, relatively little research into grandparent-grandchild relationships had been carried out until only a few years ago (Uhlendorff 2003) is due in part to the fact that a prolonged phase of life as a grandparent is a relatively recent phenomenon in historical terms. Using data from the German Socio-Economic Panel, Lauterbach (2002) is able to show that it is only since the mid-20th century that the lifetime shared by grandparents and grandchildren could generally be expected to range between two and three decades. Prior to that time, independent and reciprocal grandparent-grandchild relationships that were separate from the middle generation (cf. Robertson 1975) tended to be the exception. This demographic increase in the significance of grandparent-grandchild relationships (cf. Grünheid/Scharein 2011) has not been compensated for by the postponement of births in the life course or by the age gap between the generations which the latter has caused (Höpflinger) Humme/ 2007).

Research in this field has been subdivided into several sections: Whilst the early work initially dealt with describing behavioural expectations towards grandparents, and thus with grandparents' roles (Neugarten/Weinstein 1964; Robertson 1977), more recent work increasingly focuses on the specific nature of these roles in the sense of interactions and mutual perceptions of grandchildren and their grandparents (Werner/Lowenstein/Katz 1998), so that a dyadic perspective is opened up for the first time (Szinovacz 1998). Thereby, the recent literature connects to work on the dynamics of family relationships (e.g. the framework model of intergenerational solidarity, cf. Bengtson 2001), in which various aspects of intergenerational relationships between adults are examined. Current studies, finally, take up a familysystemic perspective in which several dyads per family (e.g. grandparent-parent and grandparent-grandchild relationships) and their interdependencies are simultaneously observed (e.g. Monserud 2008). Thereby, a real multi-level perspective is introduced in which relational, individual and family-related influences on intergenerational relationships can be modelled (Szinovacz 1998). This article adds to this by investigating the ways in which grandparent-grandchild relationships are embedded into the social family context. In addition to the influence of individual determinants, it is to be clarified what role further (intergenerational and lateral) relationships within the family system play for the cohesion between grandparents and their grandchildren. 


\section{Influences on the relationship between grandparents and grandchildren: A theoretical systematisation}

This article deals with the structure of intergenerational relationships between grandparents (G1) and their grandchildren (G3) of child and juvenile age. To describe the content of the relationship, reference is made to the works of the work group led by Vern L. Bengtson (Bengtson 2001; Bengtson/Olander/Haddad 1976; Bengtson/ Roberts 1991). The starting point of the considerations of Bengtson and his colleagues was the question of how intergenerational cohesion is achieved against the background of societal and social changes in modern industrial societies (e.g. increasing ageing, increasing demands on work-related flexibility).

The model of intergenerational solidarity distinguishes between six (later seven) aspects and dimensions: (1) associative solidarity, which especially relates to the extent and the nature of contacts; (2) affective solidarity, i.e. the perception of emotional closeness; (3) functional solidarity, which includes mutual support; (4) structural solidarity, that is the (family) structural opportunities; (5) normative solidarity, i.e. the affirmation of family values; (6) consensual solidarity, that is the level of agreement between the generations when it comes to attitudes and values, as well as (7) conflicts between the generations (Giarrusso et al. 2005). The first three dimensions are especially relevant to this article, and are also regarded as being central in the relevant literature (cf. Szydlik 2000: 38; Bengtson/Roberts 1991; Rossi/Rossi 1990: 266-296). Since, however, there is no consensus as to the causal order of these three aspects (Steinbach 2010: 224), they are treated below as one construct.

Like all social relationships, grandparent-grandchild relationships are also subject to specific social conditions which both promote and limit action. Thus, in his heuristic model of intergenerational familial solidarity Szydlik (2000: 43) distinguishes between opportunity structures, need structures, family structures and culturalcontextual structures. Since opportunities and needs vitally depend on the individual resources available (Szydlik 2000: 44), it is useful to consider resources in the systematisation of the determinants of grandparent-grandchild relationships. As a distinction vis-à-vis Szydlik's model, we therefore distinguish between personal and social resources. Personal resources include time, but also health and human capital factors (income or education), which can be contributed to, or "invested" in, the grandparent-grandchild relationship. Social resources relate to the potential and actual support within the family network. If these are not available (for instance if ties between the grandparents' and parents' generation are weak), this may impinge upon grandparent-grandchild relationships. There are now many research findings available on the impact of personal resources, but the effects of social resources have been largely unexplored so far. In addition to the available resources, normative influences in the shape of familial values and attitudes, as well as social structural determinants (e.g. gender, regional affiliation) should also be taken into account. Whilst the resources are linked to the need and opportunity structures in Szydlik's model, the social structural and normative factors mentioned correspond to the familial and cultural-contextual structures (cf. Szydlik 2000: 43-52). 
The theoretical mechanisms and empirical findings on these groups of influencing factors will be discussed below, in each case the state of research on the individual factors will be dealt with briefly.

\subsection{Personal resources}

When analysing family dyads or interaction systems, effects of personal resources of all persons involved (at least of the provider and recipient of support) are relevant in theoretical terms. As to the provider of support (in this article primarily the grandparents), one may initially expect personal resources to lead to a strengthening of intergenerational solidarity, all other things being equal. If one takes a closer look, however, the theoretical mechanisms are more complex: It is possible to presume, firstly, that the availability of resources (for instance money) generally facilitates grandparent-grandchild relationships (e.g. they can afford to undertake activities together). Insofar as the acquisition of resources (for instance through employment) uses time resources, however, one may presume the existence of a substitutional relationship of different types of resources (cf. Friedman/Hechter/Kreager 2008: 45). This may lead to antagonistic effects which can only be separated from one another when using multivariate analyses.

The outlined reasoning, albeit implicitly, stems from the perspective of intergenerational solidarity, which stresses the social integrative and pacifying nature of intergenerational relationships as "hidden connections" (Bengtson/Harootyan 1994) within society. As a contrast to this, Friedman, Hechter and Kreager (2008) pursue a Rational Choice $(\mathrm{RC})$ perspective when arguing consistently that individuals maximise their benefit, which leads to some opposing predictions (for a comparison between the two theoretical perspectives cf. Fertig 2005). Because of their advanced age, it is presumed that grandparents increasingly face the problem of how to reduce their welfare-related uncertainty at the end of their lives. Against this background, grandparents' commitment towards their grandchildren appears to be a rational decision concerning "differential investment in grandchildren" (Friedman/ Hechter/Kreager 2008: 32). Unlike in the parent-child relationship, which - already for biological reasons - is typified by a strong physical and affective closeness (Bow/by 1975), it is presumed that grandparents tend to allocate their resources more strategically in order to maximise their own welfare in old age. This also means that grandparents' commitment is primarily intended to ensure the loyalty of their own children: "through their investments in their grandchildren, we contend that grandparents primarily seek to affect their relationships with their children, rather than their grandchildren" (Friedman/Hechter/Kreager 2008: 33). These considerations imply that grandparents may in fact invest less in their relationship with their grandchildren the more personal resources they possess. All in all, according to this approach, there is a compensatory relationship between various "intermediate goods" in the family-related social production function (cf. Huinink 2005): Personal resources can partially substitute for social resources, i.e. the latter are mobilised especially when the former are not available to an adequate degree. One problem resulting from the approach is that no clear distinction is made between different 
basic needs (Friedman/Hechter/Kreager 2008: 40). Personal resources may indeed make it possible to cover basic physical needs in old age, but tend at the same time to promote self-sufficiency rather than social approval and personal affection from others. Possibly also because of this fuzziness, previous research has only partly been able to confirm the predictions derived from this approach (cf. for an overview Friedman/Hechter/Kreager 2008): Thus, studies find only sporadic, small positive effects exerted by education on the support provided to grandchildren by grandparents (Mueller/Wilhelm/Elder 2002; Mueller/Elder 2003; Uhlenberg/Hammill 1998), whilst other authors report insignificant (Cherlin/Furstenberg 1986; Fingerman 2004) or dimension-specific positive effects (e.g. on joint activities and child-care, cf. Silverstein/Marenco 2001). Inconsistent findings have also been made in the context of income: Minor positive effects in individual studies (Elder/Conger 2000; Mueller/Wilhelm/Elder 2002; Silverstein/Marenco 2001) compete with insignificant effects in others (Cherlin/Furstenberg 1986; Fingerman 2004). Controlling for income, Mueller and Elder (2003) find a weak u-shaped trend in the effect of employment on the chance of not belonging to the "detached grandparents" type. In a model with a different specification, no effect can be shown to exist using the same data (Mueller/Wilhelm/Elder 2002), so that the findings on the extent of gainful employment as a whole do not show a clear picture (cf. also Silverstein/Marenco 2001). The findings are less ambiguous with regard to grandparents' state of health, the latter strengthening the cohesion of the grandparent-grandchild relationship (Hank/Buber 2009; Höpflinger/Hummel/Hugentobler 2006). In the present article, we expect slightly positive effects of personal resources as a whole, particularly for grandparents' health. The age of the grandparents should hence affect relationships with grandchildren because it is related to life-course variations in opportunities. Hence, entering retirement age is likely to entail an increase in time resources, which can be used for joint activities with grandchildren. At the same time, advanced age is likely to entail a gradual immobilisation, for instance because of an increase in age-related illnesses influencing grandparent-grandchild relationships. Previous empirical findings are however ambiguous. Some studies do show an influence of the grandparents' age (e.g. a positive effect of age on the co-residence rate between grandparents, parents and grandchildren, Caputo 2001), but other studies do not report any significant associations (cf. for an overview Sheehan/Petrovic 2008: 107) or indeed show a negative influence (A/dous 1995). Additionally, the surveys to date, which were largely cross-sectional in nature, were unable to make out any age and cohort effects (cf. Höpflinger/Hummel/Hugentobler 2006). When it comes to the age of the grandchildren, no unambiguous effect is anticipated in this study because the age range is less relevant in terms of family cycles (e.g. no transitions take place to school or working life) and, for design-related reasons, there is relatively little age variance (cf. method part).

On the part of the support recipient, personal resources also play a role, since they indicate the need for support. Here too, the two theoretical framework models make different predictions: According to the solidarity paradigm (Bengtson 2001), solidarity should (also) include those relationships in which the recipient of support is marked by a considerable need (i.e. relatively few available resources). Accord- 
ing to the approach of selective investment, grandparents try, by contrast, to invest scarce resources primarily in those grandchildren who (or whose parents) have the best prospects to pay back (i.e. who have comparatively large amounts of resources). In empirical terms, some studies have found positive effects of the education of the grandchildren (Crosnoe/Elder 2002; Geurts et al. 2009). It can however only be decided with careful longitudinal analyses to what degree the resources of the support recipient are the cause or the outcome of solidarity. The personal resources of the grandchildren included in the present sample (aged from 8 to 15) are presumably less relevant, and furthermore are difficult to measure and vary only little (e.g. education). The theoretical arguments can however be easily applied to the middle generation, the parents, since one may presume that the grandparents' reciprocity expectations frequently focus more closely on their children (G2) than on the grandchildren (G3). In the perspective of differential investment by grandparents, this means that grandparents invest the more in the relationship with their grandchildren the more resources are available in the middle generation. According to the solidarity paradigm, grandparents should become particularly committed when the need is great - as a result of time or other restrictions in the middle generation (for instance working mothers cf. Goh 2006). Previous findings support the latter prediction (Hank/Buber 2009). Most studies however do not take the characteristics of the middle generation into account.

\subsection{Social resources}

As already indicated in the last section, it is virtually impossible to meaningfully separate grandparent-grandchild relationships from the middle parents' generation (G2) - because the grandparents' reciprocity expectations may be directed at the middle generation (Friedman/Hechter/Kreager 2008). Particularly in the case of the younger grandchildren considered in this article, the parents act as "intermediaries" in most cases, because of their coresidence and the resulting parental social control (Herlyn/Lehmann 1998; Robertson 1975). In line with this are findings according to which the grandparent-grandchild relationships are closer the stronger the parents (G2) favour the contact between grandparents and grandchildren (Mueller) Elder 2003). Although one may presume that grandparent-grandchild relationships become more independent as the grandchildren become older (Sprey/Matthews 1982), from a theoretical point of view the closeness of the grandparent-parent relationship is associated with the characteristics of positive grandparent-grandchild relationships. Goh (2006) regards a good cooperation between grandparents and parents as a necessary prerequisite for well-functioning grandparent-grandchild relationships. As was already mentioned at the outset, this question is only addressed by recent international studies, and has still been largely disregarded in Germany. In general terms, positive connections have been reported between the cohesion of grandparent-parent relationships and the frequency of child-care provided for grandchildren by grandparents (Fergusson/Maughan/Goldin 2008), as well as the strength of the grandparent-grandchild relationship among older grandchildren (Brown 2003; Crosnoe/Elder 2002; Hodgson 1992; Monserud 2008). This positive 
impact of a harmonious grandparent-parent relationship on the grandparent-grandchild relationship is more pronounced within the own lineage (Brown 2003), and appears to be enhanced in the event of a divorce in the middle generation (Bridges et al. 2007). However, it was not possible to replicate it in a study regarding grandparents' investment of time and money (Michalski/Shackelford 2005). On the basis of the theoretical arguments and of the previous findings, a clear positive impact of the cohesion between grandparents and parents on the strength of the grandparentgrandchild relationships are expected in the present study.

In addition to the intergenerational grandparent-parent relationship lateral relationships (e.g. the existence of a partner) are also potentially relevant. ${ }^{1}$ The direction of the correlation is however ambiguous: On the one hand, a partner might reduce time resources in the grandparents' generation and attract attention away from the grandchild, which should result in a negative impact on grandparent-grandchild relationships ("compensation", cf. Friedman/Hechter/Kreager 2008). On the other hand, grandparents with a well functioning relationship might have a stronger family orientation and a greater motivation towards engaging in joint activities with grandchildren, which should lead to a positive effect ("congruence" between horizontal and vertical relationships). Current research largely supports the congruence hypothesis, i.e. the cohesion of the grandparent-grandchild relationship is less pronounced among grandparents without a partner (Hank/Buber 2009) or divorced ones (King/Elder 1998; King et al. 2003; Sheehan/Petrovic 2008). As to the existence of a partner in the middle generation, the predictions are also ambiguous: Despite a potential reduction in burdens and a more intensive family orientation among partnered parents (G2), one might also presume that unpartnered parents (e.g. after separation or divorce) are keen to have a closer relationship with the grandparents. In the middle generation, unlike the positive partner effect in the grandparents' generation, positive effects are reported both of lack of a partner (Hank/Buber 2009) as well as of a divorce (Fergusson/Maughan/Goldin 2008; Johnson 1988; Kennedy/ Kennedy 1993). From the point of view of the attachment theory, the latter can be interpreted as a reflex to "move closer together" in a time of crisis. Individual studies however also show negative effects of divorce in the middle generation, e.g. on the contact frequency between grandparents and grandchildren (Geurts et al. 2009; Sheehan/Petrovic 2008), so that in sum the predictions are unclear.

\subsection{Normative and social structural influences}

By simply looking at resources (or restrictions), cultural-normative influences are neglected, which promotes theoretical monocultures in which rational determinants of human action might be overestimated (Esser 1996; Kroneberg 2005). As to internalised norms, it can be presumed that, for instance, strong familialism cog-

1 Because personal resources impact both the institutionalisation (Arránz Becker/Lois 2010) and the stability of partnerships (for an overview: Arránz Becker 2008), a multivariate view is also needed here. 
nitively "frames" relationships with relatives and hence, regardless of situational incentives, leads to a closer grandparent-grandchild relationship. The same applies to denominational ties and religiousness, which should also be linked with greater generativity (Brose 2006) and solidarity between the generations. A similar argument may explain findings of regional differences between Eastern and Western Germany: The particular historical significance of the family (Schneider 1994), as well as the tendency towards a stronger family orientation in Eastern Germany (Arránz Becker/Lois 2010), especially in the older generation, could make grandparenthood more significant and increase cohesion between grandparents and grandchildren in Eastern compared to Western Germany (Herlyn/Lehmann 1998). Whilst findings already exist of a stronger cohesion in relationships between parents and (adult) children in Eastern Germany (cf. Steinbach/Kopp 2010; Szydlik 1995, 1996), East-West differences as to grandparent-grandchild relationships have hardly been studied so far. In concurrence with the latter studies on parent-child relationships, a qualitative study finds that: "Eastern German grandmothers seek to be closer to their children and more frequently wish to help them, which is expressed in their more frequent caregiving for grandchildren" (Herlyn/Lehmann 1998: 40; translated by CPoS), which from the point of view of the authors makes clear "the particular family orientation of Eastern German grandmothers" (Herlyn/Lehmann 1998: 40; translated by $\mathrm{CPoS})$.

A social category which is also associated with differential familial orientations is the gender and the grandparents' lineage. Women have the role of the kin keeper in many societies, and are more involved in shaping kin relationships than men ( Hagestad 1986). Sociobiological approaches on the basis of evolutionary presumptions also predict that, because of their lower degree of uncertainty in comparison to grandfathers regarding their genetic similarity with their grandchildren, grandmothers should invest more in bringing up and caring for grandchildren than grandfathers (Dubas 2001; Friedman/Hechter/Kreager 2008). This permits to draw the additional conclusion that maternal grandparents (i.e. with a daughter in the middle generation) are generally more committed to their relationships with grandchildren than paternal grandparents. This hypothesis has been confirmed in various studies (Pollet/Nettle/Nelissen 2007; Sheehan/Petrovic 2008; Silverstein/Marenco 2001), albeit this effect may vary across urban vs. rural regions (King et al. 2003). In contrast, no strong theoretical presumptions exist regarding the influence exerted by the gender of the grandchildren on the relationship with their grandparents. Current studies show either closer relationships with granddaughters than with grandsons (with regard to frequency of contact: Geurts et al. 2009; on love and care, contact: Silverstein/Long 1998) or find no clear effects of the gender of the grandchildren (Höpflinger/Hummel 2006). 


\section{Dataset, analytical basis and operationalisation}

\subsection{Dataset and analytical basis: The German Family Panel (pairfam)}

The dataset for the following analyses of the shaping of grandparent-grandchild relationships refers to the parents' survey of the German Family Panel, pairfam ${ }^{2}$ (Huinink et al. 2011). In addition to the anchor persons, (step) fathers and (step) mothers were also surveyed via written questionnaires in the second survey wave of pairfam (2009/2010, release 2.0). Overall, 5,037 (step) parents of the 9,069 anchor persons took part in the survey (Suckow/Schneekloth/Wich 2010: 45). The parents' questionnaire included a section on the topic of grandchildren, with questions targeting a specific grandchild, that is, the child living in the household of the anchor person (daughter or son of the respondent) who is between 8 and 15 years old and took part in the second wave of the children's survey (cf. for the design of the pairfam survey Huinink et al. 2011). Because of this design, the analyses in this article are restricted to a specific age range of the grandchildren, in which contact is (still) largely initiated by the grandparents (and via the parents), but in which supervision and care of the grandchildren is gradually decreasing in favour of an increase in joint activities. By linking data from the anchor persons' survey, from the parents' questionnaire and from the children's questionnaire detailed information is not only obtained regarding social structural characteristics but also on relationships between the grandparents (G1), parents (G2) and grandchildren (G3) (cf. Fig. 1).

As one can see in Figure 1, the grandparents (participants in the parents' questionnaire), the parents (participants in the anchor persons' questionnaire) and the grandchildren (participants in the children's questionnaire) of a family were surveyed in the second wave of pairfam. The basis for the analysis carried out below consists of a dataset of 219 grandparent-grandchild dyadic relationships, which belong to a total of 149 families. The analyses rely on information provided by the grandparents on their relationships with grandchildren (G1-G3) and parents (G1-G2) (cf. emboldened lines in Fig. 1). Relationships between parents and grandchildren (G2-G3) were not taken into account in the final analyses since they were covered in the parenting questionnaire, and hence information is not available for all grandchildren on whom grandparents provided information. The same applies to the information from the grandchildren on the parents (G3-G2), which was not included. A test with reduced case numbers however does not show any influence exerted by the relationship between the parents (G2) and the grandchildren (G3) on the relationship between the grandparents (G1) and the grandchildren (G3). Moreover, grandchildren's assessments were not taken into account since only assessments from two parents of the anchor persons (that is grandparents of the grandchildren) are available here, whilst up to three grandparents were included in the parents' sur-

2 This article uses data from the German Family Panel (pairfam), which is coordinated by Josef Brüderl, Johannes Huinink, Bernhard Nauck and Sabine Walper. The study is funded as a longterm project by the German Research Foundation (DFG). 
Fig. 1: Assessments of relationships between various generations in pairfam (wave 2)

Generation $1(\mathrm{G} 1)$

Generation 2 (G2)

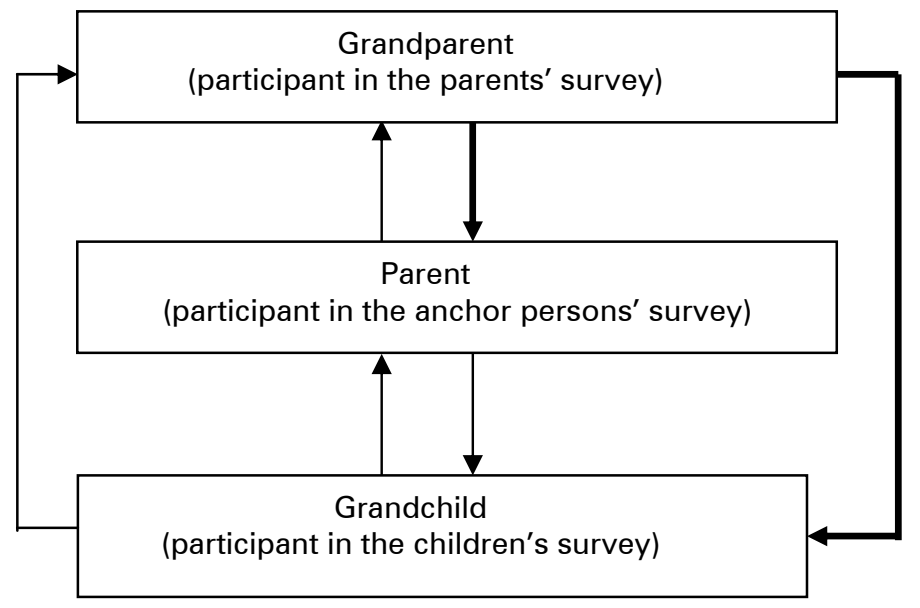

Source: own design

vey, which prevents the unambiguous linkage of the datasets for grandparents and grandchildren. The analyses furthermore do not consider parents' assessments on the grandparents (G2-G1), since correlational analyses generally do not reveal any major differences between different perspectives (Aquilino 1999; Kopp/Steinbach 2009).

Information on the parents (from the anchor dataset of waves 1 and 2) was added to this dyad dataset, so that in addition to information on the grandparent-grandchild relationships there is also information on the grandparent-parent relationships, as well as characteristics of the three generations (for a description of the variables used cf. Table 1), which were all included in the analyses.

\subsection{Dependent variable: The strength of the relationship between grandparents and grandchildren}

Since the observations in this article focus on grandparent-grandchild relationship processes, we did not only rely on one aspect, but studied three central aspects of intergenerational relationships: associative, affective and functional solidarity (cf. Szydlik 2000: 38; Bengtson/Roberts 1991; Rossi/Rossi 1990: 266-296). The dependent variable "strength of the grandparent-grandchild relationship" was formed as a mean score of grandparents' assessments on the following three variables, which all load on the same factor (Cronbachs Alpha: .57): (1) Activities with the grandchild in the last 12 months which he/she likes, such as sport, playing games or going to the cinema; (2) emotional ties in terms of speaking about the grandchild's problems in the last 12 months and (3) supporting the grandchild through larger presents of money or items (more than $€ 100$ per present) in the last 12 months. The response 
scales of the three variables each ranged from 1 "never" to 5 "very often". The mean of the index regarding the strength of the relationship between grandparents and grandchildren, at a value of 2.5 , is somewhat below the centre of the scale (cf. Table 1); concerning the individual variables of which the index is comprised, joint activities (mean value $=2.9$ ) occur more frequently than larger monetary or other presents (mean value $=1.9$ ). In terms of the frequency, speaking about the grandchild's problems lies between activities and support (mean value $=2.6$ ). Since the study of the variables mentioned (activities, speaking about problems and support) does not depend on a general subjective attitude towards the grandchild, but aims at actual interactions and investments, this strength index is particularly well suited to investigate the degree to which the quality of the relationship between the grandparents and the grandchildren depends on the available social resources such as the relationships between the grandparents and the parents, on personal resources such as the state of health, or on social structural and normative characteristics. However, before the results of the multivariate analyses are presented, something needs to be said about the operationalisation and distribution of the respective covariates.

\subsection{The operationalisation of the covariates}

On the one hand, social and personal resources can be identified as determinants of the quality of the grandparent-grandchild relationship. The social resources which are of special interest for this article include the relations between other family members who act as intermediaries on the grandparent-grandchild relationship, such as the relationship between grandparents (G1) and parents (G2) or the existence of a partnership. The personal resources which may influence the intensity of grandparent-grandchild relationships include employment status or state of health. On the other hand, however, there are social structural factors, such as the gender of the grandparents, parents and grandchildren, as well as normative determinants, such as general attitudes towards the family, which may have an impact on the grandparent-grandchild relationship. The operationalisations and the distributions of the various independent variables which have been integrated into the final analyses for this article will be described below (cf. Table 1).

Social resources. The quality of the relationship between grandparents and parents (G1-G2) as a social resource is represented by three aspects of intergenerational relationships: the associative, affective and structural solidarity dimensions (cf. Bengtson 2001), which were taken from the information provided by the grandparents (parents' questionnaire W2). (1) Associative solidarity was measured via contact frequency (visits, letters, telephone calls and the like) on a seven-level scale with the following values: 1 "daily", 2 "several times per week", 3 "once per week", 4 "1 to 3 times per month", 5 "several times per year", 6 "more rarely" and 7 "never". The members of the grandparents' and the parents' generations are in contact several times per week on average. (2) Affective solidarity was measured via two items of the "Network of Relationship Inventory" (Furman/Buhrmester 1985), which reflects the degree of intimacy and the emotional closeness between two individuals. The 
Tab. 1: Description of the sample (means and percentages)

\begin{tabular}{|c|c|c|c|c|}
\hline Factor groups & Variables & $\begin{array}{c}\text { Grandparents } \\
\qquad(\mathrm{G} 1) \\
(N=219)\end{array}$ & $\begin{array}{c}\text { Parents } \\
(\mathrm{G} 2) \\
(\mathrm{N}=149)\end{array}$ & $\begin{array}{l}\text { Grandchildı } \\
\qquad(\mathrm{G} 3) \\
(\mathrm{N}=149)\end{array}$ \\
\hline Relationship G1-G3 & $\begin{array}{l}\text { Relationship strength index }(\bar{x}) \\
\text { (1-never to } 5 \text {-very often) }\end{array}$ & $\begin{array}{c}2.5 \\
(0.7)\end{array}$ & & \\
\hline \multirow[t]{4}{*}{ Social resources } & $\begin{array}{l}\text { Contact frequency G1-G2 }(\bar{x}) \\
\text { (1-never to } 5 \text {-very often) }\end{array}$ & $\begin{array}{c}2.1 \\
(1.1)\end{array}$ & & \\
\hline & $\begin{array}{l}\text { Closeness index G1-G2 }(\bar{x}) \\
\text { (1-never to 5-very often) }\end{array}$ & $\begin{array}{c}2.9 \\
(0.9)\end{array}$ & & \\
\hline & $\begin{array}{l}\text { Distance between homes G1-G2 }(\bar{x}) \\
(0-\text { in the same household to } \\
6-3 \text { hours travelling distance and } \\
\text { longer) }\end{array}$ & $\begin{array}{c}3.1 \\
(1.7)\end{array}$ & & \\
\hline & Partnership: yes $(\%)$ & 81.1 & 91.8 & \\
\hline \multirow[t]{3}{*}{ Personal resources } & Employment: yes (\%) & 26.3 & 66.7 & \\
\hline & $\begin{array}{l}\text { Health }(\bar{x}) \\
\text { (1-poor to 5-very good) }\end{array}$ & $\begin{array}{l}3.3 \\
(0.9)\end{array}$ & $\begin{array}{c}3.6 \\
(1.0)\end{array}$ & \\
\hline & $\begin{array}{l}\text { Age }(\bar{x}) \\
\text { Cohort 3: } 1971-73(\%)\end{array}$ & $\begin{array}{c}64.2 \\
(6.2)\end{array}$ & 92.2 & $\begin{array}{l}10.6 \\
(2.0)\end{array}$ \\
\hline \multirow{3}{*}{$\begin{array}{l}\text { Social structural and } \\
\text { normative } \\
\text { characteristics }\end{array}$} & Gender: female (\%) & 61.2 & 70.8 & 49.3 \\
\hline & Place of residence: West (\%) & & 73.3 & \\
\hline & $\begin{array}{l}\text { Familialism index }(\bar{x}) \\
\text { (1-not at all to } 5 \text {-completely) }\end{array}$ & $\begin{array}{l}3.0 \\
(0.8)\end{array}$ & $\begin{array}{l}3.0 \\
(0.8)\end{array}$ & \\
\hline
\end{tabular}

Source: pairfam wave 2 (release 2.0), own calculations, $n=219$ (standard deviations from the means in brackets).

exact formulations of the two items read as follows: a) How often do you tell your son/daughter what you are thinking about? And b) How often do you share your secrets and innermost feelings with your son/daughter? The response scale ranged from 1 "never" to 5 "always". The two items were averaged to form a mean index (Cronbachs Alpha: .77). As in all surveys on intergenerational relationships in which emotional closeness, intimacy or satisfaction with the relationship was considered (cf. for an overview Steinbach/Kopp 2010), the degree of emotional closeness was also extremely high between the observed generations of the pairfam study: The average value is 4.4 , so the affective bond between grandparents and parents typically ranges between close and very close. (3) Structural solidarity between grandparents and parents was measured via the distance between the homes, and more precisely by the time required by the grandparent to reach the parent in question. The response scale was as follows: 0 "We live in the same household", 1 "We live in the same building", 2 "less than ten minutes", 3 "between ten and 30 minutes", 4 "between 30 minutes and one hour", 5 "between one and three hours" and 6 "three hours and more". Grandparents and parents live an average of roughly ten to 30 minutes apart. The partnership status was identified as a further social resource in 
the analyses, both for the grandparents' and for the parents' generations. Although the information available in the pairfam' questionnaire (parents' questionnaire W2 and anchor persons' questionnaire W2) would permit highly-differentiated classifications of the partnerships and living arrangements, a dummy variable - Person lives in a partnership or not - was included into the analyses since more fine-grained categories would have led to problems with small case numbers given the limited size of the analysis sample. When it comes to grandparents, $81.1 \%$ of respondents live in a partnership, compared to $91.8 \%$ of the parents.

Personal resources. The employment status of grandparents and parents as a personal resource was included into the analysis in form of a dummy variable (employed: yes or no): $26.3 \%$ of the grandparents are employed in one form or another, as are $66.7 \%$ of parents. Since the state of health of the individuals concerned plays a major role for intergenerational relationships, this variable was also included into the analyses as a personal resource: The grandparents (parents' questionnaire W2) and the parents (anchor persons' questionnaire W2) were asked to estimate how good their general state of health had been in the last year using a five-level selfassessment ranging from 1 "very bad" to 5 "very good". The mean value of the responses is at 3.3 with the grandparents and thus slightly lower than the estimation of the parents, which is at 3.6. As a further social structural variable, the age of the members of the three generations was also included, as a consequence of the design of the survey: For instance, the range of the age of the grandchildren, from 8 to 15, is an eligibility criterion for participation in the children's survey. The average age of the grandchildren is then 10.6 years. Since, therefore, the children had to be at least eight at the time of the interview, it is also clear that no parents (anchor persons) in this specific sample belong to the first birth cohort (1991-1993). It comes as no surprise that the members of the second birth cohort (1981-1983) are also represented in the analysis sample with a total of only $7.7 \%$. A clear majority of the parents, at $92.2 \%$, belongs to the third birth cohort (1971-1973). Hence, the birth cohort of the parents (G2) is not controlled for in the multivariate analyses. The age of the grandparents in the sample ranges from 43 to 82 , with an average of 64.2 years.

Social structural and normative influencing variables. The gender of the members of the three generations was included as an important social structural variable which can be expected to exert an influence on the characteristics of relationships within the intergenerational structure. The sample (Table 1) reveals that both genders are represented unequally with regard to grandparents and parents: Grandmothers accounted for $61.2 \%$ of the sample and mothers for $70.8 \%$. More parents of mothers evidently took part in the study, including more grandmothers than grandfathers. Granddaughters and grandsons are represented in the sample in roughly equal shares of $49.3 \%$ and $50.7 \%$. Regional differences were included as the last social structural influencing variable: in form of a dichotomous variable Western vs. Eastern Germany; this information is based on the parents' place of residence (anchor persons W1). $73.3 \%$ of the parents lived in the old Federal States (Länder) at the time of the survey. Agreement with family norms of mutual intergenerational support was recorded both in the grandparents' generation (parents' 
questionnaire W2) and in the parents' generation (anchor persons' questionnaire W2) using a scale in which the respondents were to state how much they agreed on six different items on mutual family support (e.g. "Parents should financially support their adult children if necessary"). The response scale ranged from 1 "not at all" to 5 "completely". The items of the scale which all loaded on one factor were averaged to form a mean index (Cronbachs Alpha $=.66$ ). With a mean of 3.0, the members of both generations are in each case right in the middle of the theoretically possible range, with an almost normal distribution.

\section{The results}

The results of a multi-level model are used below in order to answer the question of the degree to which the quality of grandparent-grandchild relationships is influenced by social and personal resources, as well as by social structural and normative characteristics. The index described above, which consists of the three variables on interaction, closeness and support between grandparents and grandchildren, and is to reflect the strength of the relationship, is used as dependent variable. Because of the survey design (cf. method part), the assessments come from more than one grandparent in the majority of the cases, resulting in a hierarchical data structure. In this case it is necessary to estimate a random-intercept two-level regression (cf. Luke 2004 for an introduction) since the ratio of the "between" variance to the overall variance of the dependent variables, approaching two-thirds (baseline model: $I C C=0,65$; in the baseline model the variances at both levels are significant at $p<.01$ ), is relatively large. This indicates a strong clustering of the families included in the analysis, meaning that the differences between families are predominant, whilst a relatively large degree of homogeneity is prevalent within families. The multilevel analysis makes it possible to determine which part of the variance within and between families can be explained by the inclusion of the covariates which partly represent relationship characteristics and grandparents' characteristics (Level 1), and partly characteristics of parents and grandchildren (Level 2). A combined model for grandfathers and grandmothers is reported below since the effects of almost all modelled influences proves to be invariant vis-à-vis the gender of the grandparents. This approach was further supported by the fact that separate models would have once more considerably reduced the power of the statistical tests which is already limited in the initial sample. In order to test whether the effects of the modelled influences significantly differs between grandmothers and grandfathers, separate models were calculated including interaction effects between the individual covariates and the gender of the grandparents (results not shown). However, only a gender-specific effect of the health of the grandparent emerged here, which was included in the model. Table 2 shows both, the results of bivariate "gross models", in which only the corresponding independent variable was controlled for, and the results of a multivariate net model, in which all covariates were simultaneously included in the analysis. 
Tab. 2: Results of a multilevel model to explain the strength of the grandparentgrandchild relationship (unstandardised coefficients)

\begin{tabular}{llcc}
\hline Factor groups & Variables & Gross models & Net model \\
\hline Social resources & Contact frequency G1-G2 & $.15^{* * *}$ & $.09^{*}$ \\
& Emotional closeness G1-G2 & $.19 * *$ & $.10^{*}$ \\
& Distance between homes G1-G2 & -.03 & .01 \\
& Partnership G1 & $.31 * *$ & $.39^{* * *}$ \\
& Partnership G2 & -.17 & -.16 \\
Personal resources & Employment G1 & -.02 & -.00 \\
& Employment G2 & .06 & .04 \\
& State of health G1 & $.12 * *$ & $.18^{* * *}$ \\
& State of health G2 & .04 & .00 \\
& Age G1 & -.00 & .01 \\
& Age G3 & -.01 & -.02 \\
Social structural and & Gender G1 (grandfather) & $-.14 * *$ & $-.13^{*}$ \\
normative characteristics & Gender G2 (father) & -.12 & -.12 \\
& Gender G3 (grandson) & .14 & .10 \\
& West G2 & $-.34 * * *$ & $-.32^{* *}$ \\
& Familialism G1 & $.13^{* *}$ & $.11^{*}$ \\
& Familialism G2 & .11 & .04 \\
Interaction effects & Health G1*grandfather & - & $-.17^{* *}$ \\
Model information & $\mathrm{r}^{2}$ Level 1 & - & .18 \\
& $\mathrm{r}^{2}$ Level 2 & - & .08 \\
& $\mathrm{n}$ & & 195 \\
\hline
\end{tabular}

Significance level: ${ }^{* *} p \leq .01,{ }^{* *} p \leq .05, * p \leq .10$

Source: pairfam wave 2 (release 2.0), own calculations

The results of the multi-level models explaining the strength of the grandparent-grandchild relationship in Table 2 show that both the contact frequency and emotional closeness between grandparents and parents as social resources have a positive impact on the relationship between grandparents and grandchildren. The effect coefficients slightly decrease in the net model, ${ }^{3}$ but even after controlling for various social structural characteristics of the members of the three generations, as well as their resources and attitudes, the relationship between grandparents and

3 More detailed analyses (not presented in the table) show that the effects of contact frequency and of emotional closeness (G1-G2) are partly caused by systematic differences between grandmothers and grandfathers: After controlling for the gender of the grandparent, the coefficients remain significant $(p<.05)$, but tend to become smaller (to $b=.12$ or $b=.14$ ). 
parents exerts a significant positive influence on the relationship between grandparents and grandchildren: The more frequently grandparents and parents are in touch with one another, and the stronger their emotional closeness, the stronger is also the relationship between grandparents and grandchildren. These results conform to the research (cf. e.g. Monserud 2008) and to the hypotheses on the intermediary nature of relationships between grandparents and parents. However, the distance between places of residence - as a structural condition of intergenerational relationships - does not clearly affect the strengths of the relationships between grandparents and grandchildren. Furthermore, the existence of a partnership in the grandparents' generation plays a major role as a social resource. If the grandparent has a partner, the strength of the relationship with the grandchild is much greater than if there is no partnership. The effect increases further if one controls for other covariates (net model). It is evident that the integrating resource effect of a partnership is predominant, as was also found in other surveys (e.g. Hank/Buber 2009). If the grandparents live in a partnership, both the grandfather and the grandmother act as a part of the family relationship system. One may presume that a partnership operates as a catalyst in the grandparents' generation because, for instance, one grandparent benefits if contacts are initiated by the other grandparent. The same can also be presumed to apply to the other characteristics of the relationship. For instance, in an existing partnership, the available financial resources are also likely to be greater, which has a positive impact on financial transfers from grandparents to grandchildren. With regard to the personal resources of the grandparents' and parents' generations, it is surprising that the employment status does not influence the quality of the relationship between grandparents and grandchildren. Additionally, further multivariate models were calculated in which, instead of the employment status, working hours, as well as the level of education and income, were controlled for. In these analyses, which are not presented here in detail, no effects of resources were found in the grandparents' and parents' generations. Equally, there were no effects of the number of children (G2) and grandchildren (G3).

The state of health, on the contrary, exerted a positive influence (cf. the findings for instance of Hank/Buber 2009). In the model shown here, the strength of the effect of the state of health however depends on the gender of the respective grandparent: The positive main effect of the grandparent's health $(b=.18)$ is to be interpreted conditionally because of the interaction effect, and relates to the reference category of grandmothers. The significant interaction effect health*grandfather (b $=-.17$ ) shows that health exerts virtually no influence with grandfathers (total of main and interaction effect: $b=.18+(-.17)=.01)$. Healthy grandmothers in particular evidently manage to establish and maintain a markedly strong relationship with their grandchildren. The age of the grandparents and the grandchildren, by contrast, does not have any effect at all, either as a linear or as a quadratic term.

Regarding the social structural characteristics of family members, a gender effect is shown in the grandparents' generation: Grandmothers have a stronger rela- 
tionship with their grandchildren than grandfathers do. ${ }^{4}$ This once more confirms the "kin keeper" hypothesis, which states that relationships between generations run via the female line, in other words that the women in the family hold the generations together through interaction, emotional ties and a flow of resources (cf. Dubas 2001; Hagestad 1986; Rossi 1993). The gender of the members of the parents' and grandchildren's generation, by contrast, makes no difference regarding the quality of the grandparent-grandchild relationship. Interestingly, a strong East-West difference can be identified, both in bivariate terms and after controlling for the various covariates: Relationships between grandparents and grandchildren who live in the new Federal Länder are stronger than those with grandchildren in the old Federal Länder (regarding the greater closeness of the relationships between generations in Eastern Germany cf. also the results of Steinbach and Kopp 2010 as well as Szydlik $1995,1996)$. No effects of religious affiliation or of religiosity were found in additional analyses which are not shown here.

A greater degree of grandparents' affirmation of norms of mutual intergenerational support exerts a positive impact on the strength of the grandparent-grandchild relationship. The familialism of the parents, by contrast, does not affect the grandparent-grandchild relationship.

Finally, one should mention the model information at the end of Table 1, which shows that greater variance in the grandparent-grandchild relationships can be identified within families by including the covariates $\left(r^{2}\right.$ level $\left.1=.18\right)$ than between families $\left(r^{2}\right.$ Level $\left.2=.08\right)$. The variances on both levels however also remain significant in the net model (in each case $p<.01$ ).

\section{Conclusion}

This article studied various types of influence on the cohesion of grandparentgrandchild relationships - measured via aspects of associative, affective and functional solidarity. A special focus here was on embedding grandparent-grandchild relationships in the further family relationship system, which is composed of various lateral (e.g. affinal) and vertical (intergenerational) relationships. Virtually no studies have been carried out so far in the German-language area, particularly regarding the latter aspect. With its multi-actor design, the German Family Panel (pairfam) offers a comprehensive data basis for this specific question.

The analyses demonstrate that grandparent-grandchild relationships should be looked at less as a pure individual or dyadic phenomenon, but more as being embedded in the further family interaction context. Summing up, it can be stated that social resources significantly influence grandparent-grandchild relationships, which

4 This effect is also to be interpreted conditionally because of the interaction effect contained in the model (Frazier/Tix/Barron 2004), and relates to the value 0 of the state of health. Since prior to the analysis the health variable was centred around 0 by subtracting the median value, the value 0 hence represents the sample mean. 
has frequently been neglected in previous research. As was expected, the middle generation takes up a kind of intermediary position (Robertson 1975), in which their relationship with the grandparents is positively associated with the cohesion of the grandparent-grandchild relationships. Additionally, the existence of a partner in the grandparents' generation also has a positive impact. All in all, hence, a pattern emerges according to which the relationships within a family system show a certain tendency towards congruency: One might presume that there are various family "relationship regimes" regarding to which (multigenerational) families clearly differ (cf. on this also the interfamilial variance share of the dependent variables of almost two-thirds). Further research is needed in order to clarify whether and under which circumstances individual family members (e.g. the grandparents) are able to compensate for dysfunctional relationships. Moreover, it was not possible with the available data to examine how grandparent-grandchild relationships develop as the grandchildren become older and - for instance through starting their own family become less dependent on their families of origin (cf. Silverstein/Long 1998).

With regard to personal resources, it was surprisingly clearly revealed that the quality of the relationships between grandparents and grandchildren is virtually not influenced by the socioeconomic characteristics of the individuals (in different operationalisation variants). This also implies that the challenges of modern societies - such as reconciliation of work and family life, as well as increasing requirements as to mobility - do not necessarily have the anticipated negative impact on solidarity between the generations. Rather, the grandparents' commitment appears to depend primarily on health-related resources (and restrictions). The gender-specific nature of the positive health effect, which was shown among grandmothers, but not among grandfathers, is particularly informative. In combination with the finding that grandmothers are more closely involved in the relationship with the grandchildren, this demonstrates that gender norms ("kin keeper" hypothesis, cf. Hagestad 1986) continue to play a major role in structuring relationships between generations. This is also shown in the finding that the gender of the grandparent mediates the effect of familialist norms - grandmothers are more family orientated and are more committed to their relationships with their grandchildren. Overall, the pattern of findings suggests that normative influences are crucial for the strength of grandparent-grandchild relationships. This is confirmed by the pronounced East-West difference, which can be interpreted as an empirical substrate of a major significance of the family in Eastern Germany which has developed as a result of historic events (cf. Arránz Becker/Lois 2010; Schneider 1994). These findings are compatible with the results of earlier studies on intergenerational relationships between adults in Eastern and Western Germany (Szydlik 1995, 1996), according to which solidarity between the generations is particularly strong in Eastern Germany. Only the insignificant effect of religion does not completely fit the otherwise coherent picture.

Finally, some restrictions of the analyses which were carried out have to be named. Firstly, we should mention the rather small case number in relation to the initial sample, which results from combining multi actor data. Consequently, simplifications had to be carried out in some places. For instance, it was not possible to include the G2-G3 relationship between parents and grandchildren in the analyses 
although this would have been a desirable contribution to the content. The same applies to the distinction between intact and separated families with regard to the middle generation, as well as between step grandparents and biological grandparents, which could have led to more differentiated findings. Moreover, the survey design did not allow a direct comparison of the maternal and paternal grandparents' lineages. These restrictions demonstrate the special problems and challenges of multi actor datasets. However, systemic questions can be investigated here for the first time which, as the analyses have shown, are extremely relevant to the study of family relationships. Particularly, interaction and value-related assessments of the various family members cannot be validly reconstrued via proxy variables, so that there is probably no alternative to multi actor designs. A final point relates to the causality of the links that have been found. Because of the cross-sectional perspective, the time dynamic of the development of family systems remains unclear. It is hence possible that grandparent-parent relationships change as a result of interactions between grandparents and grandchildren and not (only) the other way around. Similar uncertainty remains regarding the direction of the effects of some further determinants. As to the development of family relationships, later waves of the German Family Panel can be used as a comprehensive basis for analysis.

It can be summed up that the findings support the intergenerational solidarity model (Bengtson 2001), according to which relationships between generations are based on solidarity, that is they are not directly orientated towards maximising one's own benefit. This becomes particularly clear in the result that no effects could be found for the personal human capital of family members (that is of the grandparents' and the parents' generations). Approaches more strongly orientated towards (individualistic) Rational Choice arguments (Friedman/Hechter/Kreager 2008) make different predictions here, none of which could however be confirmed. More detailed analyses also did not show an effect of the number of children and grandchildren; the hypothesis of differential investment in grandchildren, as postulated by Friedman and colleagues, cannot however be directly tested with the available data since only relationships with a single grandchild per family were assessed. Despite these restrictions, the analyses presented offer a lot of important findings. Future studies should relate to these by taking more comprehensive account of the social system character of the family relationship structure.

\section{References}

A/dous, Joan 1995: New views of grandparents in intergenerational context. In: Journal of Family Issues 16,1: 104-122 [doi: 10.1177/019251395016001006].

Aquilino, William S. 1999: Two Views of One Relationship: Comparing Parents' and Young Adult Children's Reports of the Quality of Intergenerational Relations. In: Journal of Marriage and the Family 61: 858-870.

Arránz Becker, Oliver 2008: Was hält Partnerschaften zusammen? Psychologische und soziologische Erklärungsansätze zum Erfolg von Paarbeziehungen. Wiesbaden: VS Verlag [doi: 10.1007/978-3-531-91091-8]. 
Arránz Becker, Oliver; Lois, Daniel 2010: Unterschiede im Heiratsverhalten westdeutscher, ostdeutscher und mobiler Frauen. Zur Bedeutung von Transformationsfolgen und soziokulturellen Orientierungen. In: Soziale Welt 61: 5-27.

Bengtson, Vern L. 2001: Beyond the nuclear family: The increasing importance of multigenerational bonds. In: Journal of Marriage and Family 63,1: 1-16 [doi: 10.1111/j.17413737.2001.00001.x].

Bengtson, Vern L.; Harootyan, Robert A. (Eds.) 1994: Intergenerational linkages: Hidden connections in American society. New York: Springer.

Bengtson, Vern L.; Olander, Edward B.; Haddad, Anees A. 1976: The generation gap and aging family members: Toward a conceptual model. In: Gubrium, Jaber $F$. (Eds.): Time, roles, and self in old age. New York: Human Sciences Press: 237-263.

Bengtson, Vern L.; Roberts, Robert 1991: Intergenerational solidarity in aging families: An example of formal theory construction. In: Journal of Marriage and Family 53,4: 856-870.

Bowlby, John 1975: Bindung. Frankfurt: Fischer.

Bridges, Laura J.; Roe, Aamy E.C.; Dunn, Judy; O'Connor, Thomas G. 2007: Children's perspectives on their relationships with grandparents following parental separation: a longitudinal study. In: Social Development 16,3: 539-554 [doi: 10.1111/j.14679507.2007.00395.x].

Brose, Nicole 2006: Gegen der Strom der Zeit? Vom Einfluss der religiösen Zugehörigkeit und Religiosität auf die Geburt von Kindern und die Wahrnehmung des Kindernutzens. In: Zeitschrift für Bevölkerungswissenschaft 31,2: 257-282.

Brown, Laura Hess 2003: Intergenerational influences on perceptions of current relationships with grandparents. In: Journal of Intergenerational Relationships 1,1: 95-112 [doi: 10.1300/J194v01n01_09].

Caputo, Richard 2001: Grandparents and coresident grandchildren in a youth cohort. In: Journal of Familiy Issues 22,5: 541-556 [doi: 10.1177/019251301022005001].

Cherlin, Andrew; Furstenberg, Frank F. 1986: The new American grandparent: A place in the family, a life apart. New York: Basic Books.

Crosnoe, Robert; Elder Jr., Glen H. 2002: Life course transitions, the generational stake, and grandparent-grandchild relationship. In: Journal of Marriage and Family 3,1: 35-48 [doi: 10.1111/j.1741-3737.2002.01089.x].

Dubas, Judith Semon 2001: How gender moderates the grandparents-grandchild relationship. A comparison of kin-keeper and kin-selector theories. In: Journal of Familiy Issues 22,4: 478-492 [doi: 10.1177/019251301022004005].

Elder Jr., Glen H.; Conger, Rand D. 2000: Children of the land: Adversity and success in rural America. Chicago: University of Chicago Press.

Esser, Hartmut 1996: Die Definition der Situation. In: Kölner Zeitschrift für Soziologie und Sozialpsychologie 48,1: 1-34.

Fergusson, Emma; Maughan, Barbara; Goldin, Jean 2008: Which children receive grandparental care and what effect does it have? In: Journal of Child Psychology and Psychiatry 49,2: 161-169 [doi: 10.1111/j.1469-7610.2007.01840.x].

Fertig, Georg 2005: Geschwister - Eltern - Großeltern. Die Historische Demographie zwischen den Disziplinen. In: Historical Social Research 30,3: 5-14.

Fingerman, Karen L. 2004: The role of offspring and in-laws in grandparents' ties to their grandchildren. In: Journal of Family Issues 25,8: 1026-1049 [doi: $10.1177 / 0192513 \times 04265941]$. 
Frazier, Patricia A.; Tix, Andrew P.; Barron, Kenneth E. 2004: Testing moderator and mediator effects in counseling psychology research. In: Journal of Counseling Psychology 51,1: 115-134 [doi: 10.1037/0022-0167.51.1.115

Friedman, Debra; Hechter, Michael; Kreager, Derek 2008: A theory of the value of grandchildren. In: Rationality and Society 20,1: 31-63 [doi: 10.1177/1043463107085436].

Furman, Wyndol; Buhrmester, Duane 1985: Children`s Perception of the Personal Relationship in Their Social Networks. In: Developmental Psychology 21: 1016-1024 [doi: 10.1037/0012-1649.21.6.1016].

Geurts, Teun; Poortman, Anne-Rigt; van Tilburg, Theo; Dykstra, Pearl A. 2009: Contact between grandchildren and their grandparents in early adulthood. In: Journal of Family Issues 30,12: 1698 [doi: 10.1177/0192513X09336340].

Giarrusso, Roseann; Silverstein, Merril; Gans, Daphna; Bengtson, Vern L. 2005: Ageing Parents and Adult Children: New Perspectives on Intergenerational Relationships. In: Johnson, Malcom L.; Bengtson, Vern L.; Coleman, Peter G.; Kirkwood, Thomas B.L. (Eds.): Cambridge Handbook of Age and Ageing. London: Cambridge University Press: 413-421.

Goh, Esther C. L. 2006: Raising the precious single child in urban China: An intergenerational joint mission between parents and grandparents. In: Journal of Intergenerational Relationships 4,3: 5-28 [doi: 10.1300/J194v04n03_02].

Grünheid, Evelyn; Scharein, Manfred G. 2011: On developments in the mean joint lifetimes of three-and four-generation families in Western and Eastern Germany: A model calculation. In: Comparative Population Studies - Zeitschrift für Bevölkerungswissenschaft 36,1: 41-76 [doi: 10.4232/10.CPoS-2011-01en].

Hagestad, Gunhild O. 1986: The family: Women and grandparents as kin-keepers. In: Pifer, Alan; Bronte, Lydia (Eds.): Our aging society: Paradox and promise: Norton: 141-160.

Hank, Karsten; Buber, Isabella 2009: Grandparents caring for their grandchildren: Findings from the 2004 Survey of Health, Ageing and Retirement in Europe. In: Journal of Family Issues 127: 53-73 [doi: 10.1177/0192513X08322627].

Herlyn, Ingrid; Lehmann, Bianca 1998: Großmutterschaft im Mehrgenerationenzusammenhang. Eine empirische Untersuchung aus der Perspektive von Großmüttern. In: Zeitschrift für Familienforschung 10,1: 27-45.

Hodgson, Lynne Gershenson 1992: Adult grandchildren and their grandparents: The enduring bond. In: The International Journal of Aging and Human Development 34,3: 209-225.

Höpflinger, François; Hummel, Cornelia 2006: Heranwachsende Enkelkinder und ihre Großeltern im Geschlechtervergleich. In: Zeitschrift für Gerontologie und Geriatrie 39: 33-40 [doi 10.1007/s00391-006-0343-0].

Höpflinger, François; Hummel, Cornelia 2007: Enkelkinder und Grosseltern-alte Bilder, neue Generationen. In: Wahl, Hans-Werner; Mollenkopf, Heidrun (Eds.): Alternsforschung am Beginn des 21. Jahrhunderts. Alterns- und Lebenslaufkonzeptionen im deutschsprachigen Raum. Berlin: Akademische Verlagsgesellschaft: 99-119.

Höpflinger, François; Hummel, Cornelia; Hugentobler, Valérie 2006: Teenage grandchildren and their grandparents in urban Switzerland. In: Swiss National Science Foundation for the promotion of scientific research. National Research Programme NRP 52.

Huinink, Johannes 2005: Räumliche Mobilität und Familienentwicklung. Ein lebenslauftheoretischer Systematisierungsversuch. In: Steinbach, Anja (Eds.): Generatives Verhalten und Generationenbeziehungen. Festschrift für Bernhard Nauck zum 60. Geburtstag, Wiesbaden: VS Verlag: 61-84. 
Huinink, Johannes et al. 2011: Panel Analysis of Intimate Relationships and Family Dynamics (pairfam): Conceptual Framework and Design. In: Zeitschrift für Familienforschung 23,1: 77-101.

Johnson, Collean L. 1988: Ex familia: Grandparents, parents, and children adjust to divorce, New Brunswick: Rutgers University Press.

Kaufman, Gayle; Elder Jr., Glen H. 2003: Grandparenting and age identity. In: Journal of Aging Studies 17,3: 269-282 [doi: 10.1016/S0890-4065(03)00030-6].

Kennedy, Gregory E.; Kennedy, CE 1993: Grandparents: A special resource for children in stepfamilies. In: Journal of Divorce and Remarriage 19: 45-68.

King, Valarie; Elder Jr., Glen H. 1998: Education and grandparenting roles. In: Research on aging 20,4: 450-474 [doi: 10.1177/0164027598204004].

King, Valarie et al. 2003: Relations with grandparents. Rural Midwest versus urban southern California. In: Journal of Family Issues 24,8: 1044-1069 [doi: 10.1177/0192513X03255464].

Kivnick, Helen Q. 1982: Grandparenthood: An overview of meaning and mental health. In: The Gerontologist 22,1: 59-66 [doi: 10.1093/geront/22.1.59].

Kopp, Johannes; Steinbach, Anja 2009: Generationenbeziehungen. Ein Test der intergenerational-stake-Hypothese. In: Kölner Zeitschrift für Soziologie und Sozialpsychologie 61,2: 283-294 [doi: 10.1007/s11577-009-0054-9].

Kroneberg, Clemens 2005: Die Definition der Situation und die variable Rationalität der Akteure. Ein allgemeines Modell des Handelns. In: Zeitschrift für Soziologie 34: 344-363.

Lauterbach, Wolfgang 2002: Großelternschaft und Mehrgenerationenfamilien - soziale Realität oder demographischer Mythos? In: Zeitschrift für Gerontologie und Geriatrie 35,6: 540-555 [doi: 10.1007/s00391-002-0128-z].

Luke, Douglas A. 2004: Multilevel modeling, Thousand Oaks. London/New Delhi: Sage.

Michalski, Richard L.; Shackelford, Todd K. 2005: Grandparental investment as a function of relational uncertainty and emotional closeness with parents. In: Human Nature 16,3: 293-305 [doi: 10.1007/s12110-005-1012-5].

Monserud, Maria A. 2008: Intergenerational relationships and affectual solidarity between grandparents and young adults. In: Journal of Marriage and Family 70,1: 182-195 [doi: 10.1111/j.1741-3737.2007.00470.x].

Mueller, Margaret M.; Elder Jr., Glen H. 2003: Family contingencies across the generations: Grandparent-grandchild relationships in holistic perspective. In: Journal of Marriage and Family 65,2: 404-417 [doi: 10.1111/j.1741-3737.2003.00404.x].

Mueller, Margaret M.; Wilhelm, Brenda; Elder Jr., Glen H. 2002: Variations in grandparenting. In: Research on aging 24,3: 360-388 [doi: 10.1177/0164027502243004].

Neugarten, Bernice L.; Weinstein, Karol K. 1964: The changing American grandparent. In: Journal of Marriage and Family 26,2: 199-204.

Pollet, Thomas V.; Nettle, Daniel; Nelissen, Mark 2007: Maternal grandmothers do go the extra mile: Factoring distance and lineage into differential contact with grandchildren. In: Evolutionary Psychology 5: 832-843.

Reitzes, Donald C.; Mutran, Elizabeth J. 2004: Grandparent identity, intergenerational family identity, and well-being. In: The Journals of Gerontology Series B: Psychological Sciences and Social Sciences 59,4: 213-219 [doi: 10.1093/geronb/59.4.S213]. 
Robertson, Joan F. 1975: Interaction in three generation families, parents as mediators: Toward a theoretical perspective. In: The International Journal of Aging and Human Development 6,2: 103-110.

Robertson, Joan F. 1977: Grandmotherhood: A study of role conceptions. In: Journal of Marriage and Family 39,1: 165-174.

Rossi, Alice S. 1993: Intergenerational relations: Gender, Norms, and Behavior. In: Bengtson, Vern L.; Achenbaum, W. Andrew (Eds.): The Changing Contract Across Generations. New York: Aldine de Gruyter: 191-211.

Rossi, Alice S.; Rossi, Peter H. 1990: Of Human Bonding: Parent-Child Relations Across the Life Course. New York: Aldine de Gruyter.

Ruiz, Sarah A.; Silverstein, Merril 2007: Relationships with grandparents and the emotional well-being of late adolescent and young adult grandchildren. In: Journal of Social Issues 63,4: 793-808 [doi: 10.1111/j.1540-4560.2007.00537.x].

Schneider, Norbert 1994: Familie und private Lebensführung in West- und Ostdeutschland. Stuttgart: Enke.

Sheehan, Nancy W.; Petrovic, Kimberley 2008: Grandparents and their adult grandchildren: Recurring themes from the literature. In: Marriage \& Family Review 44,1: 99-124 [doi:10.1080/01494920802185520].

Silverstein, Merril; Long, Jeffrey D. 1998: Trajectories of grandparents' perceived solidarity with adult grandchildren: A growth curve analysis over 23 years. In: Journal of Marriage and Family 60,4: 912-923.

Silverstein, Merril; Marenco, Anne 2001: How Americans enact the grandparent role across the family life course. In: Journal of Family Issues 22,4: 493-522 [doi: 10.1177/019251301022004006].

Sprey, Jetse; Matthews, Sarah H. 1982: Contemporary grandparenthood: A systemic transition. In: Annals of the American Academy of Political and Social Science 464: 91-103.

Steinbach, Anja 2010: Generationenbeziehungen in Stieffamilien. Der Einfluss leiblicher und sozialer Elternschaft auf die Ausgestaltung von Eltern-Kind-Beziehungen im Erwachsenenalter. Wiesbaden: VS Verlag [doi: 10.1007/978-3-531-92511-0].

Steinbach, Anja; Kopp, Johannes 2010: Determinanten der Beziehungszufriedenheit: Die Sicht erwachsener Kinder auf die Beziehung zu ihren Eltern. In: Ette, Andreas; Ruckdeschel, Kerstin (Eds.): Potenziale intergenerationaler Beziehungen. Chancen und Herausforderungen für die Gestaltung des demografischen Wandels. Würzburg: Ergon: 95-116.

Suckow, Jana; Schneekloth, Ulrich; Wich, Philipp 2010: Methodenbericht. Beziehungen und Familienleben in Deutschland (2009/2010), Welle 2. TNS Infratest Sozialforschung.

Szinovacz, Maximiliane E. 1998: Research on grandparenting: Needed refinements in concepts, theories, and methods. In: Szinovacz, Maximiliane E. (Eds.): Handbook on grandparenthood. Westport: Greendwood Press: 257-288.

Szydlik, Marc 1995: Die Enge der Beziehung zwischen erwachsenen Kindern und ihren Eltern - und umgekehrt. In: Zeitschrift für Soziologie 24,2: 75-94.

Szydlik, Marc 1996: Parent-Child Relations in East and West Germany shortly after the Fall of the Wall. In: International journal of sociology and social policy 16,12: 63-87 [doi: 10.1108/eb013286].

Szydlik, Marc 2000: Lebenslange Solidarität? Generationenbeziehungen zwischen erwachsenen Kindern und Eltern. Opladen: Leske + Budrich. 
Uhlenberg, Peter; Hammill, Bradley G. 1998: Frequency of grandparent contact with grandchild sets: Six factors that make a difference. In: The Gerontologist 38,3: 276-285 [doi: 10.1093/geront/38.3.276].

Uhlendorff, Harald 2003: Großeltern und Enkelkinder: Sozialwissenschaftliche Perspektiven und Forschungsergebnisse hinsichtlich einer selten untersuchten Beziehung. In: Psychologie in Erziehung und Unterricht 50,2: 111-128.

Werner, Perla; Lowenstein, Ariela; Katz, Ruth 1998: The meaning of grandparenthood: A critical review and research agenda. In: Aging: Clinical and Experimental Research 10,6: 431-439.

Translated from the original text by the Federal Institute for Population Research, for information only. The reviewed and authors' authorised original article in German is available under the title "Beziehungen zwischen Großeltern und Enkelkindern im Kontext des familialen Beziehungssystems", DOI 10.4232/10.CPoS-2012-06de or URN urn:nbn:de:bib-cpos-2012-06de6, at http://www. comparativepopulationstudies.de.

Date of submission: 25.10 .2011

Date of Acceptance: 11.04.2012

Dr. Oliver Arránz Becker ( $₫)$. Technische Universität Chemnitz, Institut für Soziologie,

09107 Chemnitz, Germany.

E-Mail: oliver.arranz-becker@soziologie.tu-chemnitz.de

URL: http://www.tu-chemnitz.de/hsw/soziologie/institut/profil/oliver-arranz-becker,

Prof. Dr. Anja Steinbach. Universität Duisburg-Essen, Institut für Soziologie, Lotharstraße 63, 47057 Duisburg, Germany. E-Mail: anja.steinbach@uni-due.de URL: http://www.uni-due.de/soziologie/steinbach.php 


\section{Comparative Population Studies - Zeitschrift für Bevölkerungswissenschaft}

wWw.comparativepopulationstudies.de

ISSN: 1869-8980 (Print) - 1869-8999 (Internet)

Published by / Herausgegeben von

Prof. Dr. Norbert F. Schneider

Federal Institute for Population Research

D-65180 Wiesbaden / Germany

Managing Editor /

Verantwortlicher Redakteur

Frank Swiaczny

Editorial Assistant /

Redaktionsassistenz

Katrin Schiefer

Language \& Copy Editor (English) /

Lektorat \& Übersetzungen (englisch)

Amelie Franke

Copy Editor (German) /

Lektorat (deutsch)

Dr. Evelyn Grünheid

\section{Layout / Satz}

Beatriz Feiler-Fuchs

E-mail: cpos@bib.bund.de

\author{
Scientific Advisory Board / \\ Wissenschaftlicher Beirat \\ Jürgen Dorbritz (Wiesbaden) \\ Paul Gans (Mannheim) \\ Johannes Huinink (Bremen) \\ Marc Luy (Wien) \\ Clara H. Mulder (Groningen) \\ Notburga Ott (Bochum) \\ Peter Preisendörfer (Mainz)
}

\section{Board of Reviewers / Gutachterbeirat} Martin Abraham (Erlangen) Laura Bernardi (Lausanne) Hansjörg Bucher (Bonn) Claudia Diehl (Göttingen) Andreas Diekmann (Zürich) Gabriele Doblhammer-Reiter (Rostock) Henriette Engelhardt-Wölfler (Bamberg) E.-Jürgen Flöthmann (Bielefeld) Alexia Fürnkranz-Prskawetz (Wien) Beat Fux (Zürich) Joshua Goldstein (Rostock) Karsten Hank (Köln) Sonja Haug (Regensburg) Franz-Josef Kemper (Berlin) † Michaela Kreyenfeld (Rostock) Aart C. Liefbroer (Den Haag) Kurt Lüscher (Konstanz) Dimiter Philipov (Wien) Tomáš Sobotka (Wien) Heike Trappe (Rostock) 